\title{
Investment in treasury bills and treasury bonds in 2013: A study of Bangladesh
}

\author{
Bijoy Chandra Das
}

Department of Banking, University of Dhaka, Dhaka, Bangladesh

Email address:

bijoycd2013@gmail.com

\section{To cite this article:}

Bijoy Chandra Das. Investment in Treasury Bills and Treasury Bonds in 2013: A Study of Bangladesh. International Journal of Economics, Finance and Management Sciences. Vol. 2, No. 2, 2014, pp. 182-187. doi: 10.11648/j.ijefm.20140202.20

\begin{abstract}
This paper investigates that the excess investment in Treasury Bills \& Treasury Bonds in 2013 in Bangladesh was more profitable than other investment such as loans \& advances for Banks (Conventional Commercial Banks) \& other Financial Institutions (FIs). In 2013, country's political situation was fully disfavor of real sector investment and Banks did not increase their loans \& advances to increase their profitability but Banks had to bear the costing of deposit. So Banks \& other FIs suffered from excess liquidity problem. To control the situation Bangladesh Bank (BB) sold more T-Bills \& TBonds to control the excess liquidity position.
\end{abstract}

Keywords: Credit Growth, Liquidity, Money Market, Profitability, Treasury Bills, Treasury Bonds

\section{Introduction}

Banks \& other Financial Institutions (FIs) want to earn and increase their profitability (short term objective) as well as try to sustain in the market (loan term objective) ${ }^{1,2}$. At the political unrest situation in 2013 in Bangladesh, Banks \& other FIs were under threat to do their regular business activities to generate the profit. Declining real sector investment growth impacted on the growth of loans $\&$ advances of the Banks \& other FIs. On the other hand, Banks \& other FIs counted the interest on deposit. So that they went to safer investment in T-Bills \& T-Bonds to decrease the costing of cost of deposit and earned some profit $^{3}$. This topic is selected to present the real situation of investment in T-Bills \& T-Bonds in 2013 by Banks \& other FIs as well as why they went to this type of investment more.

The investment in Treasury Bills and Treasury Bonds is much safer than other investment because the owner of these T-bills \& T-bonds is the government of the nation ${ }^{4}$. Generally the default risk of the government is almost zero ${ }^{5}$ (e.g.Greece is exceptional ${ }^{6}$ ). Financial institutions such as banks, finance companies as well as insurance companies and individuals are the investors of these securities ${ }^{7}$. Primarily T-Bills \& T-Bonds are sold by Bangladesh Bank (Central Bank of Bangladesh) on behalf of the government of Bangladesh to Banks, Finance Companies (FCs), insurance companies. Buying and selling of T-bills \& T- bonds by Bangladesh Bank (Central Bank) is the mechanism of open market operation which is one of the important tools of controlling money supply to stabilize the economy as well as increase the employment ${ }^{8}$.

T-bill is the short-term debt obligation backed by the Bangladesh government with a maturity of less than one year?. T-bills are sold in multiple of BDT1,00,000 and commonly have maturities of 91 Days, 182 Days \& 364 Days ${ }^{10}$. T-bills are issued through a competitive online bidding process at a discount from par, which means that rather than paying fixed interest payments like conventional bonds, the appreciation of the bill provides the return to the holder ${ }^{11}$. After the auction, the bills can be sold in the interbank market.

T-bond is fixed-interest bearing debt security with a maturity of more than one year such as 02 years, 05 years, 10 years, 15 years and 20 years $^{12}$. Treasury bonds make interest payments semi-annually and the income that holders receive is tax free ${ }^{13}$. A competitive online bid states the rate that the bidder is willing to accept; it will be accepted depending on how it compares to the set rate of the bond. After the auction, the bonds can be sold in the interbank market.

The collection of money from the money market by government is increasing gradually over the year. To control the inflation and the development of the economy are the main objectives of collecting money from the money market ${ }^{14}$. It is an important tool of monetary policy 
but question is that why our government's borrowing is increasing? Or Is it the indicator of controlling inflation? Or Is it the indicator of decreasing credit or advances or investment opportunities at private sector? Or Is it the technique to reduce the costing of the cost of deposit or cost of fund of the banks? Or Is it the technique to generate some profit at that unrest political situation?

\section{Structure of the Financial Market in Bangladesh}

The financial sector of Bangladesh is dominated by commercial banks. The main stream of funds flows from general public as deposits to corporate and government as credit. After the independence of Bangladesh, banking industry started its journey with only six nationalized commercial banks, two state owned specialized banks and three foreign banks and after 1980's banking industry achieved significant expansion with the entrance of private banks. Now, banks in Bangladesh are primarily of two types:

- Scheduled Banks: The banks which get license to operate under Bank Company Act, $1991^{15}$ (Amended in $2013^{16}$ ) are termed as Scheduled Banks such as Sonali Bank Limited ${ }^{17}$ \& Dhaka bank Limited ${ }^{18}$ etc.

- Non-Scheduled Banks: The banks which are established for special and definite objective and operate under the acts that are enacted for meeting up those objectives, are termed as Non-Scheduled Banks such as Grammen Bank ${ }^{19}$. These banks cannot perform all functions of scheduled banks.

There are 56 scheduled banks in Bangladesh which operate under full control and supervision of Bangladesh Bank which is empowered to do so through Bangladesh Bank Order, 1972 $2^{20}$ and Bank Company Act, 1991 (Amended in 2013). Scheduled Banks are classified into several categories which are explained below:

There are 4 State Owned Commercial Banks (SOCBs) which are fully owned by the Government of Bangladesh. Four specialized banks are now operating which were established for specific objectives like agricultural or industrial development. These banks are also fully or majorly owned by the Government of Bangladesh. There are 39 private commercial banks which are majorly owned by the private entities. Private Commercial Banks (PCBs) can be categorized into two groups such as conventional $\mathrm{PCBs}^{21}$ (31) and Islami Shariah based $\mathrm{PCBs}^{22}$ (8) are now operating in the industry. Conventional PCBs perform the banking functions in conventional fashion i.e interest based operations. Islami Shariah based PCBs execute banking activities according to Islami Shariah based principles i.e. Profit-Loss Sharing (PLS) mode. On the other hand, there are 9 Foreign Commercial Banks (FCBs) are operating in Bangladesh as the branches of the banks which are incorporated in abroad.

\section{Bond Market History of Bangladesh}

Before our independence, the use of bonds as a means of resource mobilization was virtually non-existent in Bangladesh. Immediately after liberation, the government of Bangladesh reissued long-term bonds accepting the liabilities of the Income Tax Bonds and the Defense Bonds $^{23}$ of the Pakistan government held by Bangladeshi nationals and institutions. The government also issued a 5\% non-negotiable bond to Bangladeshi shareholders of nationalized industries. In addition, savings bonds were also issued to pay for the value of demonetized in 1974 . Most of these bonds are held by Bangladesh Bank. The first effort to mobilize savings for use of development expenditure was the issue of Wage Earners Development Bonds $^{24}$ in 1981 to be sold to Bangladeshi wage earners abroad. Later, a two-year special treasury bond was issued in 1984 to be sold to individuals, public and private sector organizations including banks.

During the implementation period of the financial sector reform program that took effect from 1990, nationalized commercial banks, specialized banks and development financial institutions had to make considerable provisions for huge classified loans ${ }^{25}$. As a result, the capital base ${ }^{26}$ of those banks and financial institutions eroded severely and their viability was seriously threatened. In this situation, the government issued a series of bonds to restructure the capital base of these banks and financial institutions as well as to assume the liabilities of the bad loans ${ }^{27}$ made to a number of public sector organizations.

Some bonds were also issued to mobilize funds for a number of public sector organizations like Bangladesh Biman $^{28}$. Following is the list of bonds issued by the government on various occasions: 15 years treasury bond (issued in 1990), 3 years Jatiya Biniyog Bond (issued in 1985), interest-free treasury bond (issued in 1988), treasury bond to specialized banks (issued in 1993), 3 years T\&T bond (issued in 1993), 3 years special treasury bond (issued in 1993), 15 years treasury bond (issued in 1993), 25 years treasury bond (issued in 1993), 3 years treasury bond (issued in 1994), interest free treasury bond (issued in 1994) and 2 years treasury bond (issued in 1995), 3 years T\&T bond (issued in 1994), 3 years treasury bond (issued in 1995), 3 years $\mathrm{T} \& \mathrm{~T}$ bond (issued in 1995), 3 years jute treasury bond (issued in 1995), 25 years treasury bond (issued in 1994), 5 years Biman treasury bond (issued in 1995), 3 years jute treasury bond (issued in 1995), 25 years jute treasury bond (issued in 1995), 15 years agriculture treasury bond (issued in 1996), 3 years T\&T bond (issued in 1996), 3 years treasury bond (issued in 1997), 5 years Biman treasury bond (issued in 1997), 3 years T \& T bond (issued in 1999), 10 years jute treasury bond (issued in 1995), 5 years Biman treasury bond (issued in 1998), 5 years Biman treasury bond (issued in 1998), 10 years BSC treasury bond (issued in 1998), 10 years jute treasury bond (issued in 1995), 3 years T\&T bond (issued in 1999) and 3 years treasury bond (issued in 2000). 
Marketability of bonds issued in the country was very limited up to 2005 as there was no secondary market ${ }^{29}$ for trading of these instruments. The banks, majority of which were government owned, held these bonds. There were provisions for holding of these bonds by the individuals and non-bank financial institutions also but response from them was minimum due mainly to maturity profile and non-flexibility in the rate return offered on those instruments. These were held by the banks due to the government allocation system, as well as to maintain Statutory Liquidity Requirements (SLR).

In October, 2004 Islamic Investment Bonds ${ }^{30}$ (Islamic Bonds) in accordance with Islamic Shariah was introduced for investments by the Bangladeshi Institutions and individuals and non- resident Bangladeshis, who are willing to share profit or loss. These Bonds are of 6 Months, 1 Year and 2 Year maturities and are quite attractive to the investors due to short maturity profile and flexible attractive return.

To mobilize long-term fund from domestic sources for financing government expenditure program Bangladesh Government Treasury Bonds (BGTB), bearing half yearly coupon interest, with tenors of 5 years, 10 years, 15 years and 20 years have been introduced. These bonds are issued at par through yield based multiple price auction mechanism held in Bangladesh Bank with effect from 2007.Recently 2 years treasury bond has been introduced in the market which also bears half yearly coupon interest.

The most important event in the history of Bond market in Bangladesh is that from January 10, 2005 Bonds are being traded in the secondary market. A total of 18 Bonds were listed in Dhaka Stock Exchange for trading in the market. It may be noted that Bangladesh Bank appointed primary dealers to facilitate development of bond market in the country and till today (August, 2010) 15 Primary Dealers comprising of banks and non-bank financial institutions are engaged in freely sale /purchase of bonds issued through auction mechanism. Primary dealers also get necessary support from Bangladesh Bank in case fund shortages. Since government is the single borrower in the bond market, the rates offered in other government savings instrument basically determine the yield structure of bond market. Given the nature and duration of maturities, yields had been relatively low for the bonds issued in the market as compared to the government savings instruments. This is clearly against the traditional rule of high risk-high return and vice versa which significantly impeded the growth of bond market in the country. Recently a declining trend in interest rate is being observed in the bond market, generating a relatively flat yield curve at the long end which desirable in anchoring inflation. Despite all these development, the overall situation of bond market in Bangladesh is not satisfactory due to absence of corporate bonds. The presence of a vibrant corporate bond market has strong and positive effect in reducing dominance of bank lending in private enterprises and to ensure competitive structure of rate of interest in the economy reflecting opportunity cost of money which is still lacking.

\section{Secondary Market Trading}

Participant Banks holding T-bills \& T-bonds may sell their holdings to other Banks, institutions or their clients. The terms of the secondary market transaction is mutually agreed upon by the buying and selling parties using any mode of communication agreeable to both parties (e.g., phone, fax or in person). This is called over-the-counter (OTC) $)^{31,32}$ trading, i.e., as opposed to trading on an organized exchange. The Central Depository Bangladesh Limited $(\mathrm{CDBL})^{33}$ system has facility to allow participants to enter direct transfer or deliver and receive instructions online which the system will match in the latter case. The system will record debits and credits corresponding to matched deliver and receive instructions on the specified settlement date if there is sufficient balance in the delivering participant's securities account. With this infrastructure, transfers of ownership in the T-bills \& Tbonds electronic registry will be undertaken directly into the investor's account.

Individual and institutions resident in Bangladesh are eligible to purchase T-bills \& T-bonds. Non-resident individual and institutions also are eligible to purchase these with foreign currency but are not allowed to sale within one year of purchase. In accordance with government fund raising program, T-bills \& T-bonds are issued by the Bangladesh Bank through online auction system at cut-off prices. Auctions are held as per auction calendar prepared and announced prior to each financial year on the basis of government debt management strategy. The Primary Dealers act as the underwriters and market makers with commitments to bid in auctions. The unsold portion of the bond in any particular auction is devolved to the banks and other financial institutions. The bonds (Primary Issues) are issued by Bangladesh Bank, at coupon rates, which are determined at the auction dates and are payable at six monthly intervals from the date of issue. Banks and financial institutions maintaining current account with Bangladesh Bank including the PDs, may submit bids on own account and on behalf of others for face value amount in multiples of BDT 1,00,000.00. Separate bids for will be submitted for bonds of different maturities. Bangladesh Bank also participates in bond market (both primary and secondary) for maintaining desired yield curve on residual amount not accepting by the market participants. Allowing market first, Bangladesh Bank assumes position for market development as well as macroeconomic stability of the country.

Until 2003, there was no secondary market for T-bills \& T-bonds transaction in Bangladesh. Government had decided to introduce the secondary T-bills \& T-bonds market with a vision of broadening the government securities market. Citibank N.A. and Prime Bank Limited had taken part in the first secondary transaction. Citibank N.A. had sold a T-bond of 2 years maturity bearing BDT 
3,00,00,000.00 of face value to Prime Bank Limited. Bangladesh Bank had taken necessary steps to assist that transaction. This was regarded the first secondary T-bond transaction in our country. Bangladesh Bank had selected eight banks and one non-bank financial institutions as primary dealers (PDs) to handle secondary transactions of T-bills and other government bonds.The eight banks were Sonali Bank, Janata Bank, Agrani Bank, Prime Bank Ltd, Uttara Bank Ltd, South-East Bank Ltd, Jamuna Bank Ltd, and NCCBL, and the only NBFI is International Leasing and Financial Services Ltd. But now there are 15 primary dealers where 12 commercial banks and 3 finance companies exist. The inter-bank Repo is one kind of secondary market for T-bills \& T-bonds which was introduced from July 27, 2003. The Bangladesh Bank earlier invited applications from all scheduled banks and financial institutions and directed interested parties to drop applications to the Foreign Exchange Reserve and Treasury Management Department of the central bank latest by August 21, 2003. A total of 18 commercial banks and 1 non-bank financial institution filed their applications for receiving PD licenses during the stipulated time. Central bank earlier issued a guideline for the PDs with a view to activating and streamlining the country's secondary bond market. Under the guideline, the PDs will subscribe and underwrite primary issues and make secondary trading deals with two way price quotes. A PD won't short sell any particular issue and won't carry a short position in secondary dealings. The PDs won't act as inter-bank or inter-dealer broker; it was specified in the guidelines. In Bangladesh, Multiple-units Auction Model is followed. Two types of bids may be submitted at the auction: Competitive bids, Non-competitive bids. Competitive bids $^{34}$ specify both the quantity of the security sought and a yield. If the specified yield is within the range accepted at the auction, the bidder is awarded the entire quantity sought unless the specified yield is the highest rate accepted, in which case the bidder is awarded a prorated portion of the bid. Noncompetitive bids ${ }^{35}$ specify only the quantity of the security sought.

\section{Total Investment in T-Bills \& T-Bonds and Rate of Returns in 2013}

Last year (in 2013), total collection (borrowing) by government from banking sector was BDT77,875.00 crore from selling T-bills and BDT20,100.00 crore from selling T-bonds. In 2014, it may be BDT80,000.00 crore from selling T-bills and BDT20,500.00 crore from selling Tbonds.

In 2013, the total investment in T-Bills \& T-Bonds (separate tenor based) and average Rate of Return (AROR) is shown at table and data are collected from "www. bangladeshbank. org/monetaryactivity /auc_calendar". We see that the rate of return of 91 days T-bill was lowest of all patterns of T-Bills and the rate of return of 2 years T-bond was lowest of all patterns of T-bonds.

Table. Total investment in T-Bills \& T-Bonds (Tenor based) and average rate of return (BDT in Crore).

\begin{tabular}{clll}
\hline & Tenor & Amount & $\begin{array}{l}\text { Average Rate of } \\
\text { Return }\end{array}$ \\
\cline { 2 - 4 } Treasu \\
ry Bills & 91 Days & $39,150.00$ & $8.67 \%$ \\
& 182 Days & $19,550.00$ & $10.13 \%$ \\
& 364 Days & $19,175.00$ & $10.55 \%$ \\
& 2 Years & $3,000.00$ & $10.80 \%$ \\
Treasu & 5 Years & $7,700.00$ & $11.71 \%$ \\
ry & 10 Years & $6,100.00$ & $12.14 \%$ \\
Bonds & 15 Years & $1,800.00$ & $12.35 \%$ \\
& 20 Years & $1,500.00$ & $12.44 \%$ \\
\hline
\end{tabular}

At the beginning of the year in 2013, rate of return of 91 days T-bill was almost $10.00 \%$ but ending of the year it was decreased to $7.12 \%$ which was less than Repo rate (7.25\%). Equally thinking about 182 days T-bills and 364 days T-bills, rate of return of 182 days T-bills was $11.05 \%$ at the beginning of the year and $8.14 \%$ at the ending of the year. Lastly the rate of return of 364 days T-bills was $11.38 \%$ at the beginning of the year and $8.78 \%$ at the ending of the year. But average rate of return on T-Bond was almost stable over the year rather than 2 years T-Bond.

If we consolidated the rate of returns of all T-bills and Tbonds, Average Rate of Return (AROR) would be $11.10 \%$. That means, if we invested BDT100,000.00 in T-bill or Tbond, income would be BDT11,100.00 in a year where the cost of deposit of the banks was $8.56 \%$ (www.bangladeshbank.org) \& in amount was BDT8,560.00. So that net income of the banks was $2.54 \%$ \& in amount was BDT2,540.00).6. Investment Strategy of Banks and the Rate of Return on T-Bills and T-Bonds

\section{SLR Requirement and Excess Liquidity Position of the Banks}

Every Bank has to maintain Cash Reserve Ratio (CRR) and Statutory Liquidity Reserve (SLR) requirements on its Total Demand and Total Time Liabilities (TDTT) to fulfill the compliance of the central bank. Now CRR is $6.00 \%$ for Conventional Banks as well as Islamic Banks but SLR is $13.00 \%$ for Conventional Banks and $5.50 \%$ for Islamic Banks which was $19.00 \%$ \& $11.50 \%$ accordingly ${ }^{36}$. SLR requirement was changed by Bangladesh Bank's DOS Circular No.-01, dated 19/01/2014 and the effective date was 1st February, 2014.

CRR is maintained at cash form with Bangladesh Bank and SLR is calculated by total investment amount in T-bills \& T-bonds, excess amount of CRR, foreign exchange reserve with Bangladesh Bank ${ }^{37,38}$. Banks can purchase Tbills and T-bonds from central bank through Primary Dealer (PD) based on competitive online bid. Any bank can maintain whole $13.00 \%$ (Conventional Banks) of SLR requirement by purchasing T-bills and T-bonds. 
In 2013, excess liquidity in the market was BDT83,000.00 crore and it was happened because of decreasing the private sector credit growth ${ }^{39}$. Excess liquidity position means availability of excess fund beyond the amount of CRR \& SLR requirements and idle fund of the banks. So that banks invested that excess fund at T-bills or T-bonds to offset the cost of deposit or to generate some profit. If banks did not do this, they put up with the cost of deposit or loss of the profit. Most of the banks earned more than BDT100.00 crore from investing in T-bills and Tbonds at that time of lending crisis.



Fig. How excess liquidity helps to minimize the cost of deposit.

Figure shows that the result of availability of the fund and reducing the credit growth, Banks \& other FIs got an alternative safe investment scope in T-Bills \& T-Bonds which helps to reduce the costing of cost of deposit as well as they generate some profit.

\section{Credit Growth Rate in 2013}

The political situation of the country in 2013 was very susceptible to the real sector investment and many business firms were unable to continue their business activities as regular manner. Most of the business firms calculated huge losses by failing to keep the commitment of the shipment of goods and small business firms decided to shutdown their business activities. New investors were scared to start their business and existing businesses were not expanded.

Targeted private sector credit growth rate was $16.50 \%$ for first half year of the monetary policy 2013-14 but actual private sector credit growth was $11.10 \%$ (Monetary Policy January-June, 2014). Private sector credit growth rate was declined by $5.40 \%$ which is indicated that investors were not interested to invest. That time investors did not take credit facilities from banks and others financial institutions. So that Banks \& other FIs suffered from excess liquidity at hand.

\section{Offsetting the Cost of Deposit}

Bank deals with others money and it has to bear the interest cost on deposit whether deposited money is invested or not. Credit is the main income generated product of the banks but banks did not increase this. They always search alternative scope of investment to recover the cost of deposit. Otherwise banks could bear huge losses

In 2013, average cost of deposit of the banks was equal to $8.56 \%$ (www.bangladesh-bank.org) which was lower than the rate of return on T-Bills and T-Bonds (11.10\%). That means banks recovered the cost of deposit as well as earned much profit from investing in T-Bills and T-Bonds. If banks did not do this, they would bear $8.56 \%$ cost of deposit and fallen under trouble.

\section{Investment Strategy of Banks and the Rate of Return on T-Bills and T-Bonds}

Every investor bank took short term investment strategy and banks were very aggressive to buy 91 Days or 182 Days or 364 Days T-bills and the rate of return on T-bills was declined. They thought that political situation will be normal at near future \& real sector investment will be increased as well as credit growth will be increased. So they did not go to the long term investment such as TBonds.

\section{Conclusion}

Banks \& other FIs should invest their liquid fund at safer places such as T-Bills \& T-Bonds although the rate of return is lower than loans \& advances. Default risk, investment \& reinvestment risk, business continuation risk, interest rate risk as well as strategic risk can be raised by giving loans \& advances where investment in T-bills \& T-bonds is risk free. Fact is that there was no alternative investment scope in that time because political factor is fully disfavor of robust real sector investment. Like other years every Bank had a profit target in 2013 but they did not achieve it without going to the investment in T-Bills \& T-Bonds. On the other hand, Banks tried to minimize the costing of deposit which was fixed and committed to pay to the depositors. So they invested more at T-Bills \& T-Bonds. Now let me conclude on a note of healthy optimism that the entrepreneurial zeal awakened in our population will not falter in their aspiration for stable, emerging credit growth in 2014. I also hope that Banks will remain supportive of investment and credit growth while being anchored to desired stability and profitability.

\section{Acknowledgement}

All praise and glory to almighty help me to finish my article.

I owe a great many thanks to a great many people who helped and supported me during the writing of this article. Without whom this article would have been a distant reality

\section{References}

[1] Narayanan, 1987, Managerial Incentives for Short-term Results, Journal of Finance, Vol. XI, No. 5 
[2] Peter, Adrian \& John, 2009, Designing long-term policy: rethinking transition management, Springer Science+Business Media, 42: 275-302

[3] Ahorny, Saunders, Swary,1985, The Effects of the International Banking Act on Domestic Bank Profitability and Risk, Journal of Money

[4] Jeff Madhura, 2008, Financial Markets and Institutions: Commercial Bank Operations, 8th Edition (Thomson SouthWestern, USA)

[5] Carlo \& Mauro, 1990, The Risk Premium on Italian Government Debt, 1976-88, IMF self papers, Vol. 37, No. 4

[6] Anna VISVIZI, 2012, The Crisis in Greece and EU-IMF rescue Package: Determinants and Pitfalls, Acta Oecomica, Vol. 62, No. 1, 15-39

[7] Van Horne \& John, 2005, Fundamental of Financial Management, 12th Edition (Prentice Hall Financial Times, England)

[8] Tarron Khemraj, 2007, Monetary Policy and Excess Liquidity, Social and Economic Study, Vol. 56, No. 3, 101127

[9] Jeff Madhura, 2008, Financial Markets and Institutions: Money Market, 8th Edition (Thomson South-Western, USA)

[10] A. R. Khan, 2000, BANK MANAGEMENT-A FUND EMPHASIS: Investment Management (Decent Book House \& Publishers, Dhaka-1205)

[11] Jeff Madhura, 2008, Financial Markets and Institutions: Money Market, 8th Edition (Thomson South-Western, USA)

[12] Kevin, 2007, Security Analysis and Portfolio Management (Prentice-Hall of India Private Limited, New Delhi)

[13] CFA Institute, 2013, Corporate Finance and Portfolio Management, Level-1 (WILEY, USA)

[14] Tarron Khemraj, 2007, Monetary Policy and Excess Liquidity, Social and Economic Study, Vol. 56, No. 3, 101127

[15] Bangladesh Bank, www.bangladesh-bank.org, Regulation and Guidelines, Dhaka, Bangladesh

[16] The Financial Express, 2013, Latest amendment to Bank Company Act, July 17

[17] Sonali Bank Limited, www.sonalibank.com.bd, Bangladesh

[18] Dhaka Bank Limited, www.dhakabank.com.bd, Bangladesh

[19] Grameen Bank, www.grameen-info.org, Bangladesh

[20] Bangladesh Bank, www.bangladesh-bank.org, Regulation and Guidelines, Dhaka, Bangladesh

[21] Thorsten, Asli, Ouarda, 1999, Comparative Efficiency of The Islamic Bank Vis-A-Vis Conventional Banks In Malaysia, Vol. 7, 1-27

[22] Abdus Samad, 2013, Islamic vs. conventional banking:
Business model, efficiency and stability, Vol. 37, 433-447

[23] Jeffrey, 2013, In defense of Barry Bonds, The Hardball Times, January 10

[24] The Wage-earner Development Bond Rules,1981, Bangladesh

[25] Development Finance and Enterprise Department, 2005, Guideline on Classification of Impaired Loans/Financing And Provisioning for Bad and Doubtful Debts, 8-10

[26] Basel II: International Convergence of Capital Measurement and Capital Standards: A Revised Framework Comprehensive Version

[27] Arun, 2014, Banking woes: How to solve India's bad debt problem, The Economic Times, March 28

[28] Bangladesh Biman, www.biman-airlines.com, Bangaldesh

[29] Finra glossary definition of secondary offering, Financial Industry Regulatory Authority, 2010

[30] Doug, 2008, EIIB: Secondary market volume has contracted significantly, sukuk.net.

[31] Garry, Modern banking and OTC derivatives markets, ISBN $1-55775-999-5,5-7$

[32] ISDA, 2010, OTC Derivatives Market Analysis, May 26, 2011

[33] Central Depositary Bangladesh Limited, www.cdbl.com.bd, Bangladesh

[34] Richard, 1983, Competitive bidding and proprietary information, Journal of Mathematical Economics, Vol. 11, No. 2, 161-169

[35] Martin, 2002, Identifying non-competitive bids in construction contract auctions, Omega, Vol. 30, No. 6, 443449

[36] NEW AGE (Online Edition), 2013, Scheduled banks asked to maintain CRR \& SLR separately, December 11

[37] Rezwanur, 2010, Daffodil International University Forum, August 03

[38] Ganti, 1995, Optimal cash Reserve Ratio in India's Liberalized Monetary System, Savings and Development, Vol. 19, No. 1, 97-102

[39] The Daily Star, 2013, Excess Liquidity Rises Further, December 15

[40] A. R. Khan, 2000, BANK MANAGEMENT-A FUND EMPHASIS: Reserve Management (Decent Book House \& Publishers, Dhaka-1205)

[41] A. R. Khan, 2000, BANK MANAGEMENT-A FUND EMPHASIS: Investment Management (Decent Book House \& Publishers, Dhaka-1205)

[42] Herbert Mayo, 2008, Investments: An Introduction, 10th edition 